\title{
Ultrastructural evidence of bacterial damage to Spongia officinalis fibres (Porifera, Demospongiae)
}

\author{
Elda Gaino, Roberto Pronzato
}

Istituto di Zoologia, Via Balbi 5, 16126 Genova, Italy

\begin{abstract}
Skeletons of healthy and damaged specimens of Spongia officinalis were examined by scanning and transmission electron microscopy. Comparisons of the fibre net demonstrated that bacterial invasion was responsible for the decay of spongin fibres in affected sponges. Bacteria were located both inside and on the surface of fibres. Irregularly shaped spaces and canals together with many orifices were visible scattered over the fibre surfaces. Tissue reparation consisted of isolation of affected areas and permitted complete recovery and regeneration of many specimens.
\end{abstract}

\section{INTRODUCTION}

Even though microbial diseases have been reported in sponges of commercial interest, the etiology of these devastating maladies is poorly understood. Fungi and bacteria are reported to cause mass mortalities that may completely destroy wide populations (see review in Lauckner 1980). Studies on bacterial diseases of Porifera are particularly difficult because sponges harbour numerous micro-organisms within the mesohyl (Sarà \& Vacelet 1973, Vacelet 1975). Microflora composition varies considerably within sponge species (Vacelet \& Donadey 1977), and reflects the species specificity of microbial symbionts within the sponge body (Wilkinson 1978, Wilkinson et al. 1981).

In an early paper, a mucoid coat covering the external surface of dying Hippospongia equina was reported to be related to bacterial invasion (Allemand-Martin 1906). We observed a white coat consisting principally of bacteria in Chondrilla nucula under experimental conditions (Gaino \& Pronzato 1987). Electron microscopic examination of these diseased specimens revealed that exogenous micro-organisms were able to penetrate into the sponge body and that some gave rise to sporogenous forms (Gaino \& Pronzato 1987). Furthermore, some sporogenous bacteria possessed damaged cell walls suggesting the presence of an active internal defence mechanism of the sponge. Sponges appear capable of inactivating pathogenic microorganisms (Nigrelli et al. 1959, Jakowska \& Nigrelli
1960 ) as well as isolating damaged portions of the body (Connes 1967) to allow the recovery of many specimens. Nevertheless, widely distributed populations have disappeared because of devasting diseases (Storr 1957).

We found diseased Spongia officinalis along the coast of Portofino, Italy (Eastern Ligurian Sea) and demonstated by scanning and transmission electron microscopy (SEM, TEM) that the spongin fibres were invaded by bacteria. These micro-organisms damage the skeleton causing it to become brittle; thereby reducing the commercial value of these sponges.

\section{METHODS}

Damaged and dying Spongia officinalis were observed from April to December 1987 within populations in 4 to $18 \mathrm{~m}$ depth. Photographic surveys were performed to monitor these organisms, and specimens collected for microscopic examination.

Immediately after collection, fragments for SEM were fixed in $2.5 \%$ glutaraldehyde in artificial seawater for $2 \mathrm{~h}$, washed, and dehydrated in a graded ethanol series. Samples were critical-point dried in $\mathrm{CO}_{2}$ and then coated with gold-palladium using coating unit E 5000 (Polaron Equipment Ltd, Watford, Herts England) and observed in an ISI DS 130 scanning electron microscope. For TEM, fragments were fixed in $2.5 \%$ glutaraldehyde in artificial seawater for $1 \mathrm{~h}$, 
rinsed, and post-fixed for $1 \mathrm{~h}$ in $1 \%$ osmium tetroxide in seawater. Fragments were dehydrated in a graded series of ethanol and embedded in an Epon-Araldite mixture. Ultrathin sections were cut on a Reichert ultramicrotome, double-stained with uranyl acetate and lead citrate, and examined in a Zeiss EM 109 electron microscope

\section{RESULTS}

Mortality in Spongia officinalis populations was evident in specimens in which the fibre skeleton was exposed to the environment. In some cases the whole sponge body was reduced to a mesh of brittle fibres or only a small portion of living tissue was retained (Fig. 1). In others, the damage was limited to a few areas (Fig. 2)

Healthy and damaged specimens contained structurally different fibres. The skeleton of healthy Spongia officinalis seen by SEM showed a framework of primary fibres, protruding outside to form conuli and linked together by a network of connecting fibres (Fig. 3). Healthy fibres had a smooth appearance and a homogeneous organization, with a concentric cortex and medulla consisting of layers (Fig. 4).

Damaged specimens showed a discontinuous network of broken fibres (Fig. 5). The outermost surface of these fibres shows laminar projections irregularly arranged along the major axis. This gives them a squamous texture (Fig. 6). Broken fibres revealed a loose core (Fig. 6).

At the TEM level, the fibres contained canaliculi opening to the outside (Fig. 7). The core was very porous with bacteria inside irregularly shaped spaces delimited by thin strands of the fibrillar matrix (Fig. 8). Bacteria averaged from 0.5 to $0.8 \mu \mathrm{m}$ diameter, and sometimes adhered to the fibrillar matrix with apparently more than $50 \%$ of their surface (Fig. 9). Bacteria were also visible adhering to the outermost surface of the fibres which showed many orifices and grooves (Fig. 10).

In spring 1987, at the beginning of our observations, about $60 \%$ of the specimens living in the examined area $\left(6000 \mathrm{~m}^{2}\right)$ were affected. In the winter of the same year, about $10 \%$ of the specimens died while survivors were able to recover by isolating damaged areas from the living tissue. This process resulted in the formation of pocket-like cavities whose walls were delimited by epithelial cells forming a colourless 'callus'. This was clearly evident over the pigmented surface of the sponge where it coexisted with the diseased areas (Fig. 2).

The surface of the cavities possessed openings of about 20 um with a central orifice (Fig. 11.). These openings belong to the aquiferous system and assure water flow in the recovering sponges.

\section{DISCUSSION}

Spongia officinalis, like most species of Porifera, harbours symbiotic bacteria in the mesohyl. Healthy specimens, however, contain no bacteria within the skeletal framework; fibres are smooth and homogeneous. Dead specimens with exposed fibres and damaged ones, in which healthy tissue had isolated the affected network of fibres, possessed bacteria-filled fibres. This feature has not been reported previously, even in other moribund species of Porifera whose destruction was considered in relation to pathogenic micro-organisms (Dosse 1940). In $S$. officinalis much of the bacterial surface is in close contact with the spongin matrix; this suggests an active involvement of these microorganisms in its dissolution. The bacteria may release enzymes able to excavate the spongin meshwork, similar to collagen resorption in sponges (Garrone 1975, Wilkinson et al. 1979). The porous internal nature of the fibres and the canaliculi of the outermost coat could both arise from enzymic digestion by such microorganisms. As a consequence the skeleton becomes brittle and unsuitable for commercial purposes. Pathogenic fungi have been described as being involved in the mortality of Porifera but in that case the damage was related almost entirely to the soft parts of the sponge body (Lauckner 1980).

The cause of mortality in Spongia officinalis cannot be verified, but fibre-invading bacteria appear to be the most probable agents for this event. It is, however, impossible to identify them, on a morphological basis, from other symbionts in the mesohyl of the sponge. It is possible that under certain physiological conditions, sponge tissues may become unable to control proliferation of symbionts. This hypothesis is consistent with data on the recently investigated mass mortalities of the marine sponge Halichondria panicea, caused by 2 common symbiotic bacteria (Hummel et al. 1988). In this species bacterial growth increased significantly with increasing temperature and decreasing waterflow. In $S$. officinalis, bacterial invasion extended from the living sponge mass into the skeleton. The openings on the fibre surface would facilitate the spreading of bacteria. In contrast, degeneration of sponges of the genus Aplysina occurs when exogenous bacteria replace the associated population (Vacelet 1979). Likewise, in Chondrilla nucula exogenous bacteria penetrate into the sponge body and show atypical morphology (Gaino \& Pronzato 1987).

Symbiont proliferation in Spongia officinalis may be responsible for fibre destruction. It is worth stressing 

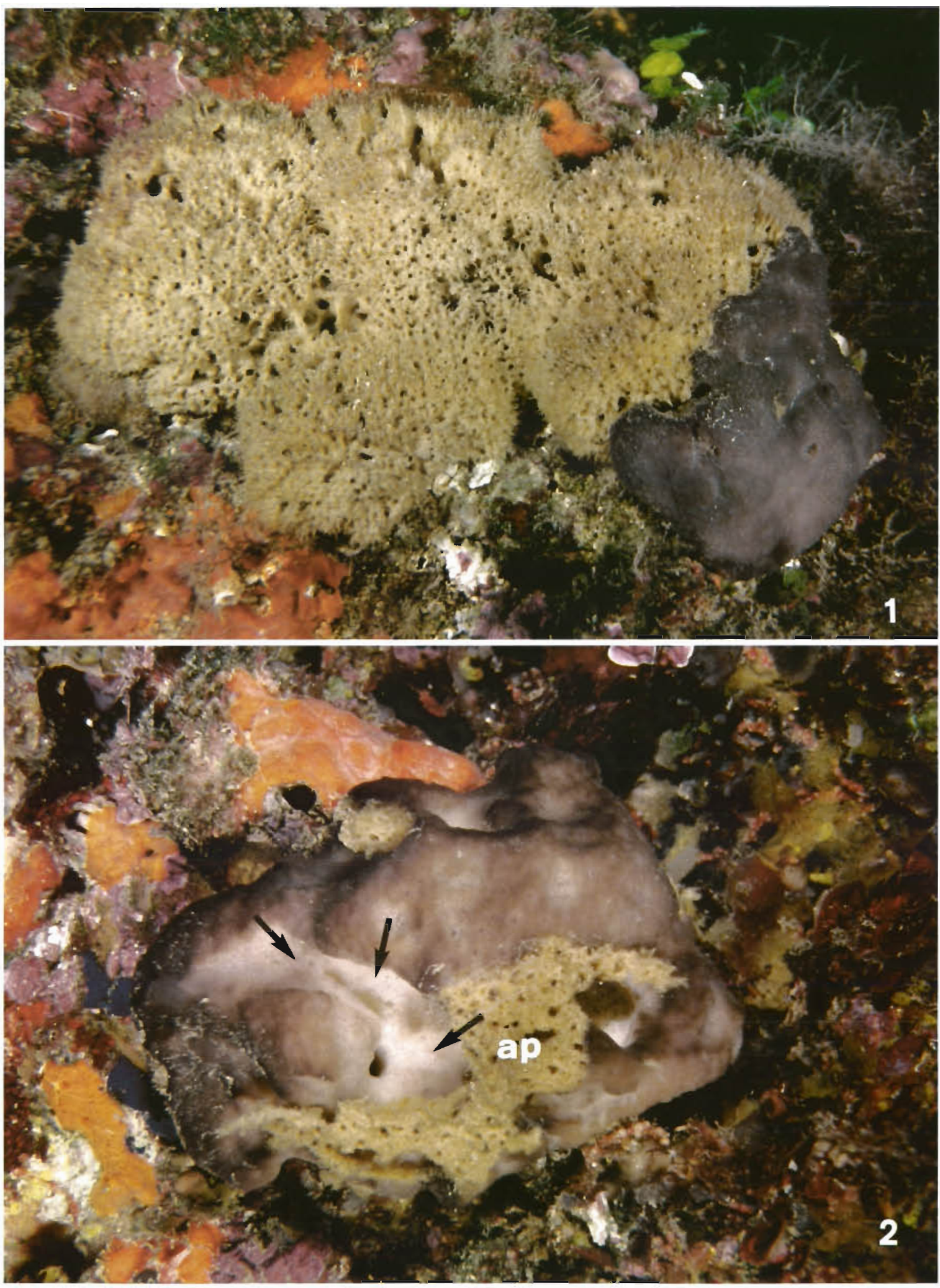

Figs. 1 and 2. Spongia officinalis. Fig. 1. Damaged specimen characterized by a pigmented area of living tissue and a skeleton of naked fibres exposed to the environment. Fig. 2. Damaged specimen showing the naked skeletal fibres of the affected part (ap) and the colourless callus-like recovered surface (arrows) 

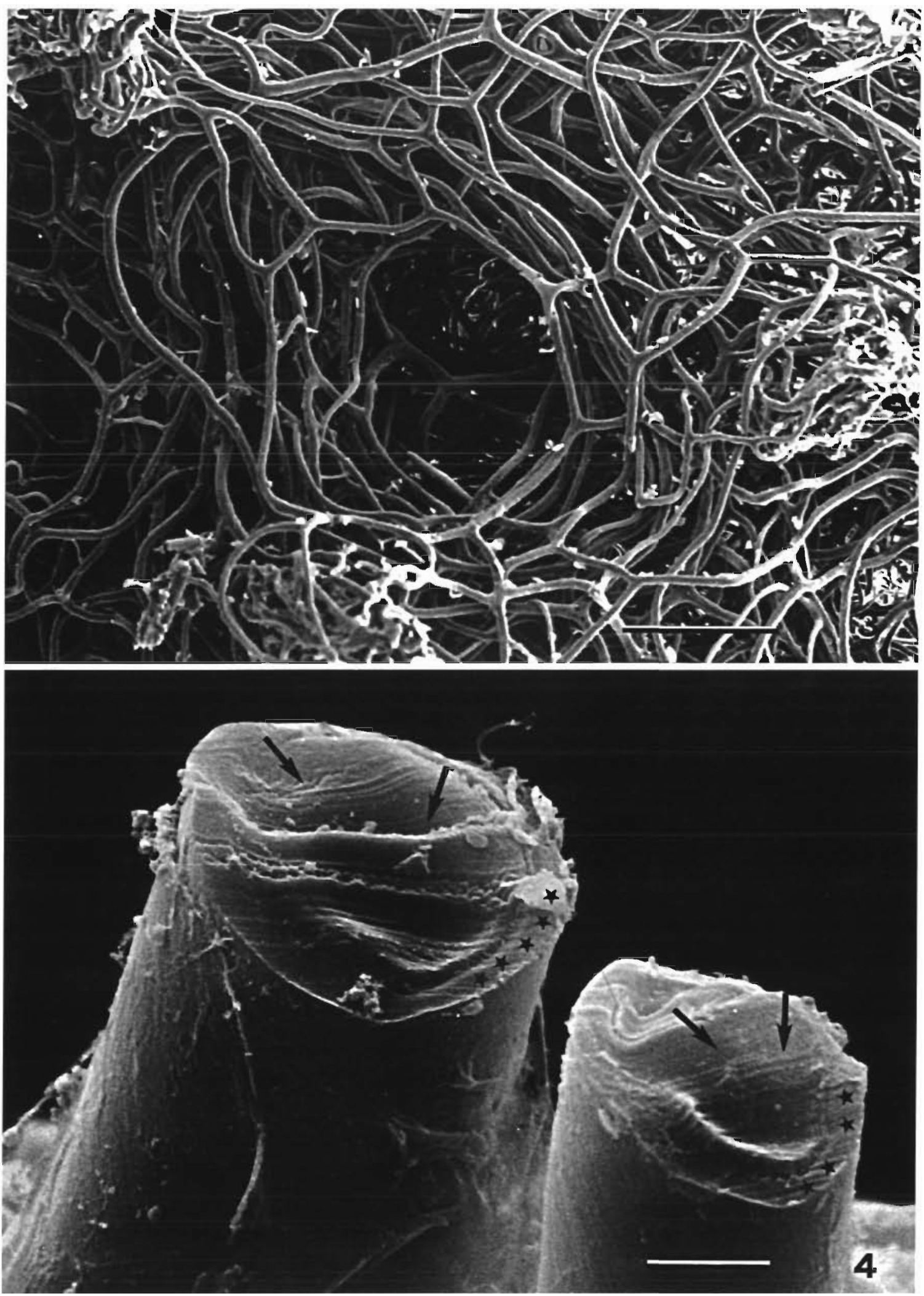

Figs. 3 and 4. Spongia officinalis. Fig. 3. Healthy specimen showing the skeletal network of fibres. SEM; bar $=200 u m$. Fig. 4. Detail of cut tibres of healthy specimen showing their fine organization of cortex (stars) and medulla (arrows) layers. SEM; bar $=$ 

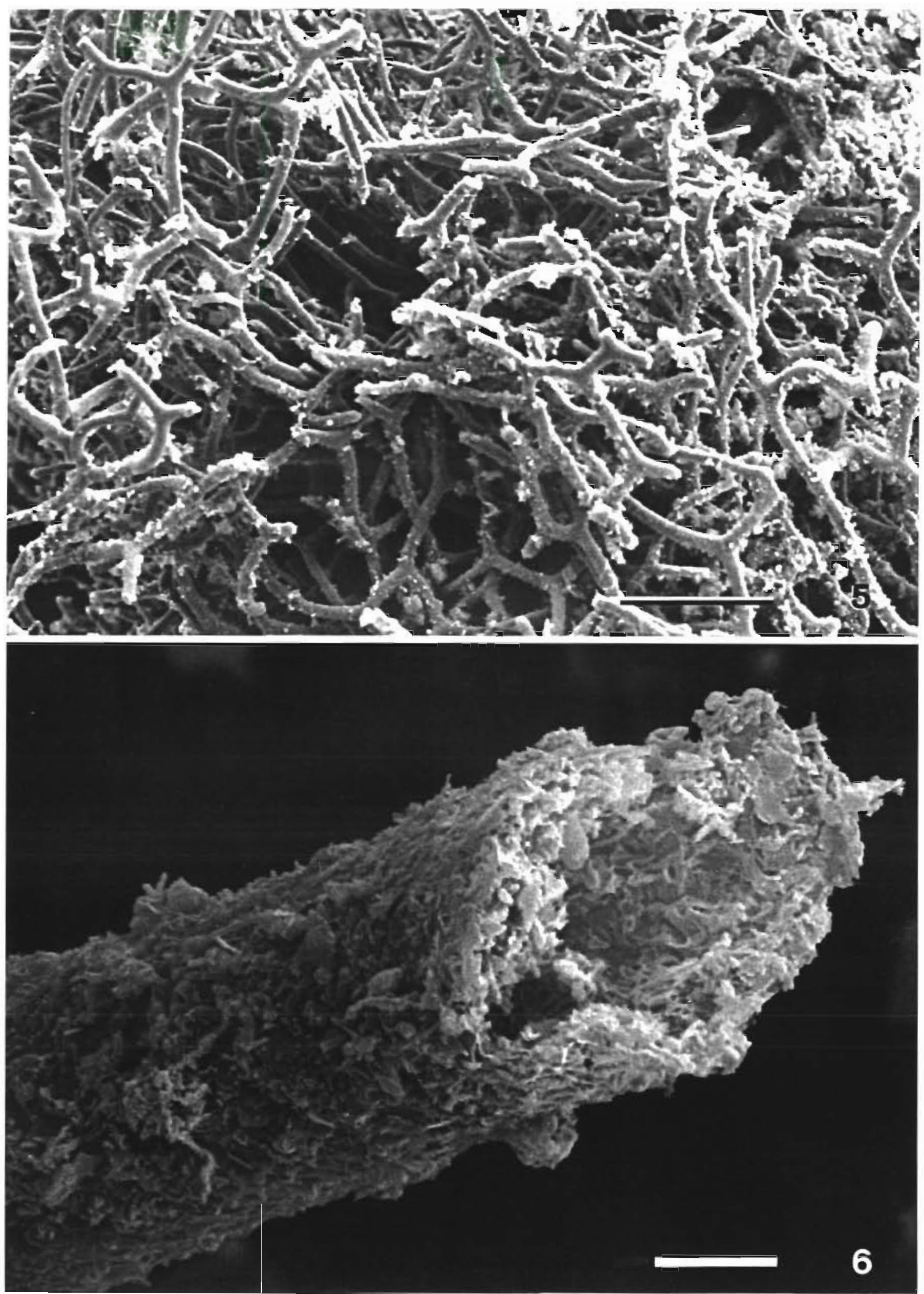

Figs. 5 and 6. Spongia officinalis. Fig. 5. Skeleton of a dead specimen showing meshwork of broken fibres. SEM; bar $=200 \mu \mathrm{m}$. Fig. 6. Detail of a cut fibre, showing squamous appearance and loosely-textured core. SEM $\mathrm{bar}^{=} 4 \mathrm{um}$ 


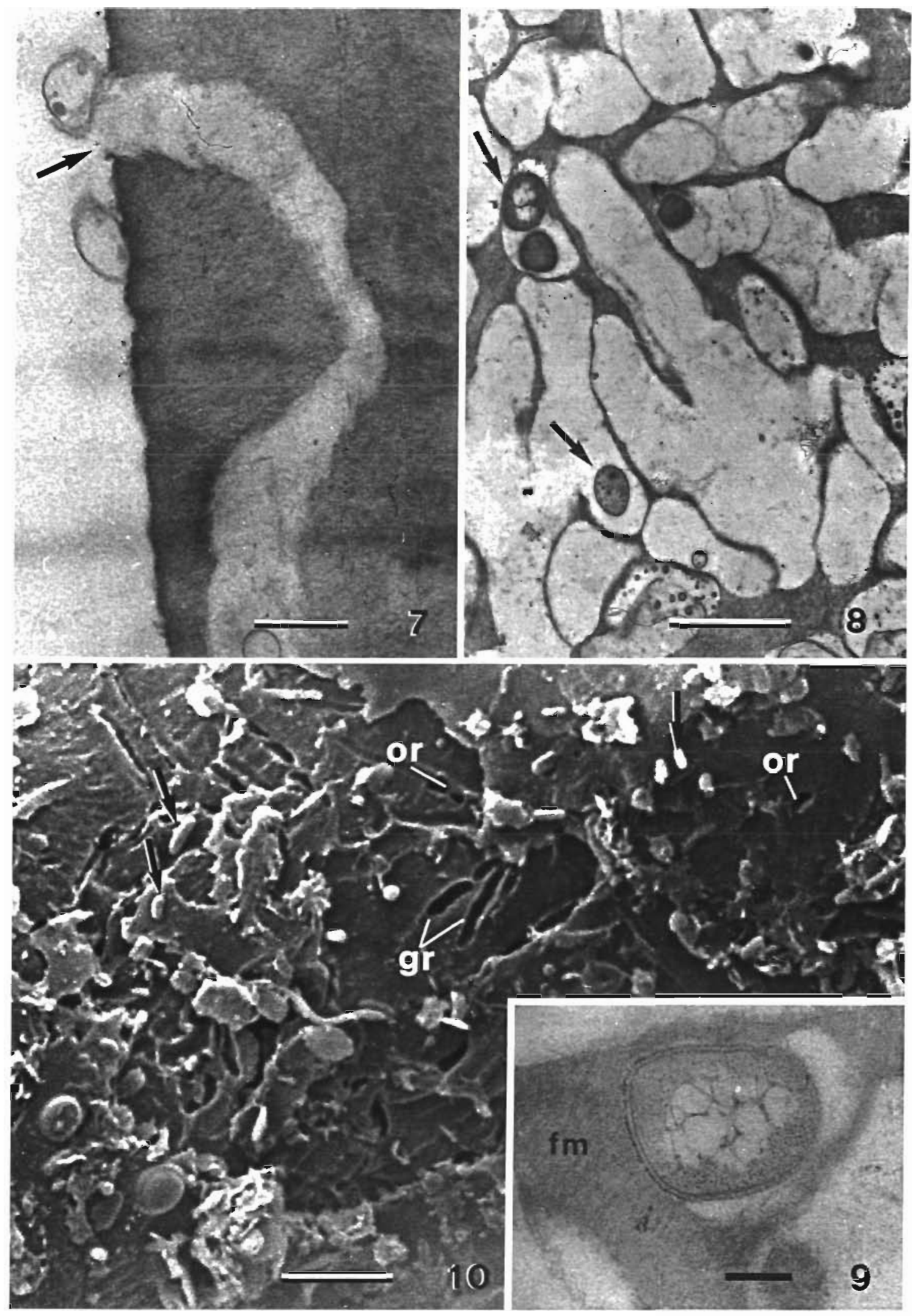

Figs. 7 to 10. Spongia officinalis. Fig. 7. Damaged specimen showing canaliculus crossing the outermost fibre surface and openung to the outside (arrow). TEM; bar $=0.5 \mathrm{um}$. Fig. 8. Section through the inner core of a damacred fiber exhibiting loose texture and some bacteria (arrows) within the porous area. TEM; bar $=1 \mathrm{um}$. Fig. 9. Magnification of a bacterium inside the porous area with a wide contact surface close to the fibrillar matrix $(\mathrm{fm}$ ) of a fibre. TEM; bar $=0.2 \mu \mathrm{m}$. Fig. 10. Fibre showing some bacteria (arrows) together with orifices (or) and grooves (gr) scattered on its outermost surface. SEM; bar $=2 u m$ 


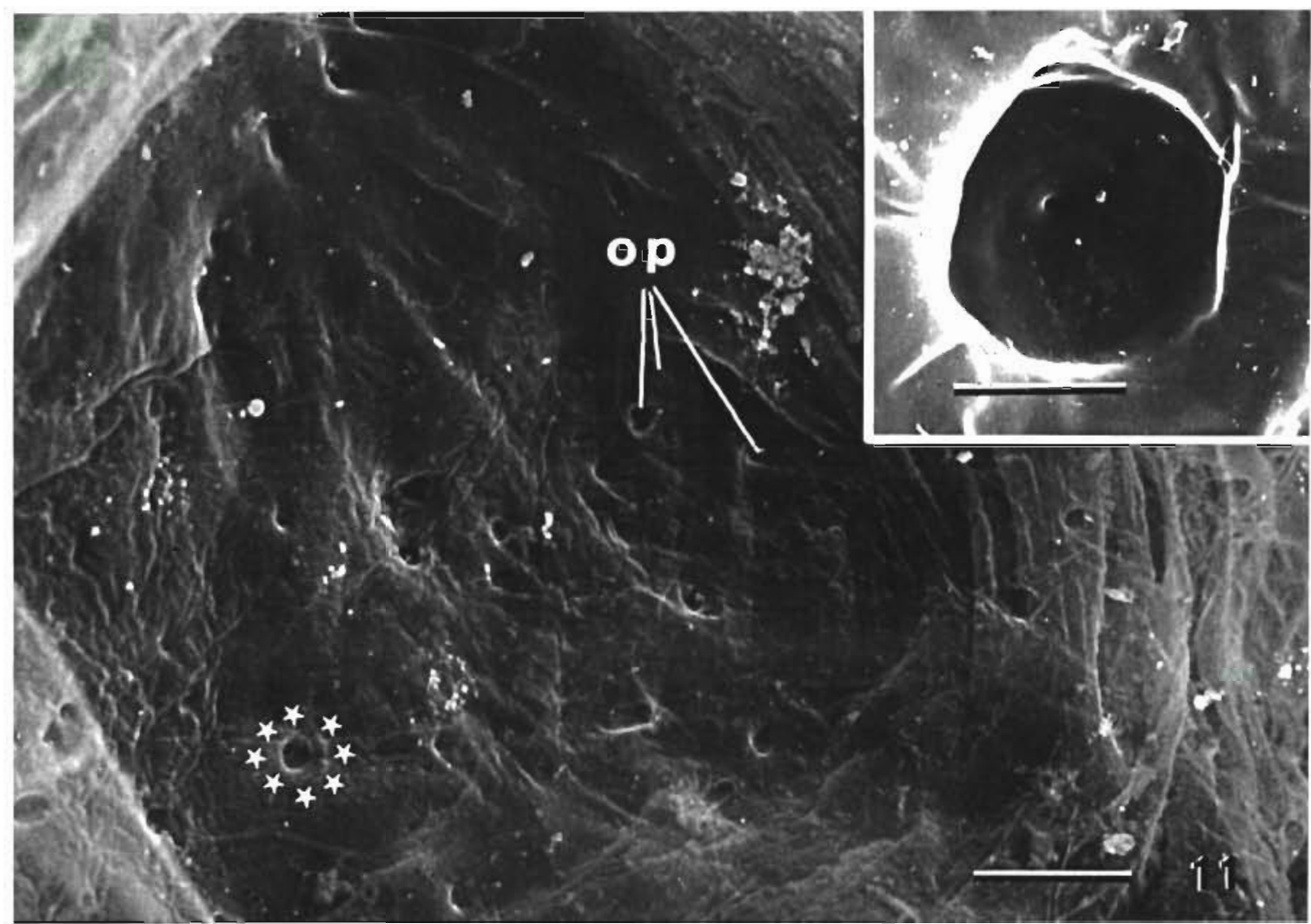

Fig. 11. Spongia officinalis. Pocket deriving from reparative processes in a recovered specimen. Aquiferous system openings (op) are visible. SEM; bar $=100 \mu \mathrm{m}$. Stars encircle the opening enlarged in the inset (bar $=12 \mu \mathrm{m}$ )

that degeneration of collagen in Chondrosia reniformis is due to the specific bacteria of that sponge (Wilkinson et al. 1979)

Marine sponges are capable of distinguishing bacterial symbionts from other bacteria and appear to be able to control them (Wilkinson et al. 1984). They also produce lectins that promote the growth of bacteria isolated by the sponge (Müller et al. 1981). High mortalities in sponges presumably relate to bacterial invasion even though many species of sponges produce antimicrobially active substances (Nigrelli et al. 1959 Jakowka \& Nigrelli 1960). More recently, products with antibiotic properties have been localized within spherulous cells of Aplysina fistularis (Thompson et al. 1983). These products appear to play a role in the protective system to reduce surface fouling. Biologically active metabolites are released by this species into seawater and are believed to reduce tissue damage resulting from larval settlement or overgrowth by other organisms (Thompson 1985, Walker et al. 1985).

Despite the absence of spherulous cells, Spongia officinalis displays an efficient self-defence mechanism against epibionts ( $M$. Pansini pers, comm.). Horny sponges in the Ligurian Sea reach very large dimensions and become very old (Pansini \& Pronzato in press). Despite this, they may be considered very susceptible to environmental conditions and their mortality may represent a large-scale epizootic event. In fact, dying $S$. officinalis specimens are not limited to the Ligurian Sea since diseased populations have also been found along other Mediterranean coasts, such as in Tunisia, Greece, Lampedusa and Sicily. In Marsala Lagoon (northwest Sicily) a rich population of $S$. officinalis (Corriero 1984) has vanished in the last few years (G. Corriero pers. comm.).

Spongia officinalis appears unable to synthesize antibiotic products against bacterial invasion, but displays a defence mechanism capable of isolating the damaged area from the sponge body. The onset of this reparative mechanism is characterized by the formation of colourless 'calluses' containing the openings of the inhalant canal systems. Tissue reorganization excludes the damaged areas and allows the water currents to flow again within the sponge. This agrees well with the autodigestion of fibres recently observed in $S$. officinalis as a part of the skeletal spongin remodelling that plays an important role in modifying the canal system and in tissue organization (Vacelet et al. 1988).

No bacteria were observed around or within the fibre network of recovered areas, thus indicating a mechan- 
ism for separating damaged tissues before bacterial invasion can spread to the whole living mass. This represents a successful host response adaptative strategy. The isolation of portions of affected sponge tissues is also known in Tethya lyncurium (Connes 1967 ) and in horny sponges associated with pathogenic fungi (Smith 1941). This defence mechanism allows the complete recovery of many affected Spongia officinalis. Even though mortalities did occur, many other specimens were able to eliminate diseased areas and survive.

Acknowledgements. We express our sincere gratitude to Dr C. Wilkinson of the Australian Institute of Marine Science, Townsville, for his critical review of the paper and his valuable suggestions. We are also very grateful to Salvatore Marcoddi for his kind technical assistance.

\section{LITERATURE CITED}

Allemand-Martin, A. (1906). Etude de physiologie appliquée sur la spongiculture sur les côtes de Tunisie. Thèse, Univ. Lyon

Connes, R. (1967). Réaction de défense de l'éponge Tethya lyncurium vis-à-vis des micro-organismes et de l'amphipode Leucothoë spinicarpa Abildg. Vie Milieu (Ser A) 18: $281-289$

Corriero, G. (1984). Note sul popolamento di Poriferi dello stagnone di Marsala (Sicilia). Nova Thalassia 6: 213-223

Dosse, G. (1940). Bakterien- und Pilzbefunde sowie pathologische und Fäulnisvorgänge in Meeres- und Süßwasserschwämmen. Untersuchungen im Zusammenhang mit dem gegenwärtigen Sterben der Badeschwämme in Westindien. Z. Parasitkde 11: 331-356

Gaino, E., Pronzato, R. (1987). Ultrastructural observations of the reaction of Chondrilla nucula (Porifera, Demospongiae) to bacterial invasion during degenerative processes. Cah. Biol. mar 28: 37-46

Garrone, R. (1975). Collagen resorption in sponges: involvement of bacteria and macrophages. In: Peeters, H. (ed.) 22nd Colloquium Protides of the Biological Fluid. Pergamon Press, Oxford, p. 59-63

Hummel, H., Sepers, A. B. J., de Wolf, L., Melissen, F. W. (1988). Bacterial growth on the marine sponge Halichondria panicea induced by reduced waterflow rate. Mar. Ecol. Prog. Ser. 42: 195-198

Jakowska, S., Nigrelli, R. F. (1960). Antimicrobial substances from sponges. Ann. N. Y Acad. Sci. 90: 913-916

Lauckner, G. (1980). Diseases of Porifera. In. Kinne, O. (ed.) Diseases of marine animals, Vol. I, General aspects, Protozoa to Gastropoda. Wiley \& Sons, Chichester, p. 139-165 Müller, W. E. G., Zahn, R. K., Kurelec, B., Lucu, C., Müller, I.,
Uhlenbruck, G. (1981) Lectin, a possible basis for symbiosis between bacteria and sponges. J. Bacteriol 145: $548-.558$

Nıgrelli, R F., Jakowska, S., Calventi, J. (1959). Ectyonin, an antimicrobial agent from the sponge Microciona prolifera Verriel. Zoologica N. Y. 44:173-176

Pansini, M. Pronzato, R. (in press). Observations on the dynamics of a Mediterranean sponge community. In: Rützler, $K$, Hartman, W. H. (eds.) New perspectives in sponge biology. Smithsonian Inst. Press, Washington D.C.

Sarà, M., Vacelet, J. (1973). Ecologie des démosponges. In Grassé, P. P. (ed.) Traité de Zoologie, Vol. III, Spongiaires. Mason, Paris, p. 462-576

Smith, F G. W (1941). Sponge disease in British Honduras, and its transmission by water currents. Ecology 22: $415-421$

Storr, J. F. (1957). The sponge industry of Florida. Educ. Ser. Fla St. Bd Conserv. 9: 28

Thompson, J. E. (1985). Exudation of biologically-active metabolites in the sponge Aplysina fistularis. I. Biological evidence. Mar. Biol. 88: 23-26

Thompson, J. E., Barrow, K. D., Faulkner, D. J. (1983). Localization of two brominated metabolites, Aerothionin and Homoaerothionin, in spherulous cells of the marine sponge Aplysina fistularis ( $=$ Verongia thiona). Acta Zool. (Stockh.) 64: 199-210

Vacelet, J. (1975). Etude en microscopie électronique de l'association entre bactéries et spongiaires du genre Verongia (Dyctyoceratida). J. Microscopie Biol. Cell. 23: 271-288

Vacelet, J. (1979). La place de spongiaires dans les écosystèmes trophiques marins. In: Lévi, C., Boury-Esnault, N. (eds.) Biologie des spongiaires, C.N.R.S. Paris, p. 259-270

Vacelet, J., Donadey, C. (1977). Electron microscope study of the association between some sponges and bacteria. J. exp. mar. Biol. Ecol. 30: 301-314

Vacelet, J., Verdenal, B., Perinet, G. (1988). The iron mineralization of Spongia officinalis L. (Porifera, Dictyoceratida) and its relationships with the collagen skeleton. Biol. Cell 62: $189-198$

Walker, R. P., Thompson, J. E., Faulkner, D. J. (1985). Exudation of biologically-active metabolites in the sponge Aplysina fistularis II. Chemical evidence. Mar. Biol. 88: 27-32

Wilkinson, C. R. (1978). Microbial association in sponges. II. Numerical analysis of sponge and water bacterial populations. Mar. Biol. 49: 169-176

Wilkinson, C. R., Garrone, R., Herbage, D. (1979). Sponge collagen degradation in vitro by sponge-specific bacteria. In. Lévi, C., Boury-Esnault, N. (eds.) Biologie des spongiaires. C.N.R.S. Paris, p. 361-364

Wilkinson, C. R., Garrone, R., Vacelet, J. (1984). Marine sponges discriminate between food bacteria and bacterial symbionts: electron microscope radioautography and in situ evidence. Proc. R. Soc. (Ser. B) 220: 519-528

Wilkinson, C. R., Novak, M., Austin, B., Colwell, R. R. (1981) Specificity of bacterial symbionts in Mediterranean and Great Barrier Reef sponges. Microb. Ecol. 7: 13-21 